\title{
Pengawasan Pelaksanaan Otonomi Daerah
}

\author{
Mhd. Ansori ${ }^{1}$ \\ Fakultas Hukum Univesitas Batanghari Jambi
}

\begin{abstract}
Abstrak
Pengawasan adalah sebagian dari wewenang pemerintahan secara menyeluruh, karena pada tingkat terakhir Pemerintah Pusat yang harus bertanggung jawab mengenai seluruh penyelenggaraan, membenarkan diadakannya pengawasan atas segala tindakan daerah, karena keutuhan Negara Kesatuan harus terpelihara. Otonomi daerah sebagai otonomi bagi rakyat daerah dan bukan otonomi "daerah" dalam pengertian suatu wilayah/teritorial tertentu di tingkat lokal, kalau implementasi otonomi daerah dilakukan Pemerintah Daerah maka kewenangan itu harus dikelola secara adil, jujur, dan demokratis. Dalam menyelenggarakan pemerintahan, pemerintah pusat menggunakan asas desentralisasi, tugas pembantuan serta dekonsentrasi sesuai dengan peraturan perundang-undangan yang berlaku, sementara itu pemerintah daerah dalam menyelenggarakan pemerintahan menggunakan asas desentralisasi dan tugas pembantuan. Tujuan tulisan ini untuk mengetahui, menganalisa pengawasan otonomi daerah. Tipe penelitian yang digunakan adalah penelitian yuridis normatif, menggunakan pendekatan konseptual, pendekatan perundang-undangan dan pendekatan sejarah.
\end{abstract}

Kata Kunci : Pengawasan, Pelaksanaan,Otonomi Daerah.

\begin{abstract}
Supervision is a part of the overall authority of the government, because at the last level the Central Government must be responsible for the whole administration, justifying the holding of supervision of all regional actions, because the integrity of the Unitary State must be maintained. Regional autonomy as autonomy for regional people and not "regional" autonomy in the sense of a particular region / territorial at the local level, if the implementation of regional autonomy is carried out by the Regional Government, that authority must be managed fairly, honestly and democratically. In administering the government, the central government uses the principles of decentralization, coadministration and deconcentration in accordance with the prevailing laws and regulations, while the regional governments in administering the government use the principles of decentralization and co-administration. The purpose of this paper is to find out, analyze the supervision of regional autonomy. The type of research used is normative juridical research, using a conceptual approach, a legislative approach and a historical approach.
\end{abstract}

Keyword : Supervision, Implementation,Regional Autonomy.

\section{PENDAHULUAN}

Penyelenggara pemerintahan daerah adalah pemerintah daerah dan DPRD, dalam menyelenggarakan pemerintahan, pemerintah pusat menggunakan asas desentralisasi, tugas pembantuan, serta dekonsentrasi sesuai dengan peraturan perundang-undangan yang berlaku, sementara itu pemerintah daerah dalam menyelenggarakan pemerintahan menggunakan asas desentralisasi dan tugas pembantuan. ${ }^{2}$ Pengertian Pemerintahan Daerah menurut Undang-Undang Nomor 9 Tahun 2015 juncto Undang-Undang Nomor 23 Tahun 2014 adalah penyelenggaraan urusan pemerintahan oleh pemerintah daerah dan dewan perwakilan rakyat daerah menurut asas otonomi dan tugas pembantuan dengan prinsip otonomi seluas-luasnya dalam sistem dan prinsip Negara Kesatuan Republik Indonesia sebagaimana dimaksud dalam Undang-Undang Dasar Negara Republik Indonesia Tahun 1945.

Dalam menyelenggarakan fungsi-fungsi pemerintahan, terutama dalam penyelenggaraan otonomi, daerah dibekali dengan hak dan kewajiban tertentu. ${ }^{3}$ Agar dapat melaksanakannya dengan baik dan benar "hukum merupakan instrumen utama dalam penyelenggaraan pemerintahan Indonesia", ${ }^{4}$ serta sikap

1 Mhd.Ansori, Dosen Fakultas Hukum Universitas Batanghari.

${ }^{2}$ Rozali Abdullah, Pelaksanaan Otonomi Luas Dengan Pemilihan Kepala Daerah Secara Langsung, (Jakarta: Rajawali Pers, 2005), hlm. 27.

3 Ibid, hlm. 28

${ }^{4}$ H.Abdul Latief, Hukum dan Peraturan Kebijaksanaan pada Pemerintahan Daerah, (Yogyakarta: UII Press, 2005$)$, hlm. 
mentalitas aparatur pemerintahan daerah merupakan salah satu kunci penting keberhasilan pelaksanaan otonomi daerah, karena merekalah ujung tombak dan eksekutor program tersebut. ${ }^{5}$

Pelaksanaan hak dan kewajiban tersebut tentu harus diawasi, karena sistem pengawasan juga menentukan kemandirian satuan otonomi, kebebasan berotonomi dan pengawasan merupakan dua sisi dari satu lembaran dalam berotonomi. ${ }^{6}$

Menurut Baswir pengawasan adalah suatu proses kegiatan yang dilakukan secara terus-menerus atau berkesinambungan untuk mengamati, memahami, dan menilai setiap pelaksanaan kegiatan tertentu sehingga dapat dicegah atau diperbaiki kesalahan atau penyimpangan yang terjadi. ${ }^{7}$ Pengawasan menjadi suatu kalimat yang agak menakutkan bagi Pemerintah Daerah, bukan saja karena implikasi dari pengawasan itu sendiri, tetapi juga dari banyaknya pengawasan, bagi Pemerintah Daerah, hal tersebut seperti permainan kuis bergambar serupa tapi tak sama. ${ }^{8}$

Dari uraian tulisan diatas maka penulis merumuskan masalah yang terbatas pada "Bagaimanakah pengawasan pelaksanaan otonomi daerah?"

Tujuan tulisan ini untuk mengetahui dan menganalisa pengawasan pelaksanaan otonomi daerah berdasarkan peraturan perundang-undangan di Indonesia.

Pengawasan otonomi daerah yang dilakukan Pemerintah Pusat melalui wakilnya terkadang mengganggu kemandirian otonomi daerah, tentunya diperlukan aturan yang tepat agar terlaksana dengan baik.

Pemikiran pentingnya pembagian kekuasaan telah diterjemahkan kedalam sendi kehidupan bernegara yang artinya dalam setiap kekuasaan harus terdapat kekuasaan lain yang mengawasi, pentingnya pengawasan ini menurut John Stuart Mills adalah demi melindungi kepentingan kaum pinggiran, minoritas, atau rakyat banyak. ${ }^{9}$

Pengawasan bertujuan agar pelaksanaan berbagai urusan pemerintahan di daerah dapat berjalan sesuai dengan standar dan kebijakan pemerintah pusat, berdasarkan peraturan perundang-undangan yang berlaku. ${ }^{10}$

Secara skematis, pengawasan dibedakan dua jenis, yaitu "pertama pengawasan administratif yang berbentuk pengawasan melekat dan pengawasan fungsional, dan yang kedua pengawasan oleh kekuasaan kehakiman, baik secara keperdataan maupun secara administratif'. ${ }^{11}$ Pendapat dari Paulus Efendi Lotulung "pengawasan adalah upaya untuk menghindari terjadinya kekeliruan-kekeliruan, baik disengaja maupun tidak disengaja, sebagai usaha preventif, atau juga untuk memperbaikinya apabila sudah terjadi kekeliruan itu, sebagai usaha represif". ${ }^{12}$

Konsep pengawasan secara garis besar dibedakan menjadi dua macam yaitu:

a. Pengawasan preventif, yaitu berupa hak memberikan pengesahan terlebih dahuku terhadap semua keputusan daerah sebelum peraturan daerah dijalankan.

b. Pengawasan represif, berupa hak menunda atau membatalkan sesuatu keputusan daerah (yang belum atau sudah berjalan) yang dianggap bertentangan dengan kepentingan umum, undang-undang, peraturanperaturan yang lebih tinggi tingkatannya. ${ }^{13}$

Masih dalam hal pengawasan, yang "sifatnya fakultatif yaitu dalam rangka memberikan pertimbangan kepada Pemerintah Daerah terhadap rencana yang menyangkut kepentingan daerah"14 dan dapat menjadi

\footnotetext{
5 Hasan Mustafa, "SDM dan Otonomi Daerah", (Palu: 2002), hlm. 5.

${ }^{6}$ Bagir Manan, Menyongsong Fajar Otonomi Daerah, (Yogyakarta: Pusat Studi Hukum FH UII, 2001), hlm. 39.

7 Ihyaul Ulum MD, Audit Sektor Publik, (Jakarta: Bumi Aksara, 2009), hlm. 129.

${ }^{8}$ Lihat Sebastian Schrnieg, "DPRD dan Pengawasan", http://sebastianschrnieg. wordpress.com, tanggal diakses 16
} Agustus 2018.

${ }^{9}$ O.C.Kaligis, Pengawasan Terhadap Jaksa Selaku Penyidik Tindak Pidana Khusus dalam Pemberantasan Korupsi, (Bandung: PT.ALUMNI, 2006), hlm. 33.

${ }^{10}$ Rozali Abdullah, Op.Cit., hlm. 180.

11 Muchsan,Sistem Pengawasan Terhadap Perbuatan Aparatur Pemerintah dan Peradilan Tata Usaha Negara di Indonesia,(Yogyakarta: Liberty, 2007), hlm. 39.

12 Paulus Effendie Lotulung dalam Irfan Fachruddin, Pengawasan Peradilan Administrasi Terhadap Tindakan Pemerintah, (Bandung: PT.Alumni, 2004), hlm. 89.

${ }^{13}$ B.N.Marbun, Otonomi Daerah 1945-2005 Proses dan Realita, (Jakarta: Pustaka Sinar Harapan, 2005), hlm. 59.

14 Juanda, Hukum Pemerintahan Daerah Pasang Surut Hubungan Kewenangan Antara DPRD dan Kepala Daerah,(Bandung: PT.Alumni, 2008), hlm. 285. 
"sarana dalam menciptakan check and balances system pelaksanaan pemerintahan sampai pada tingkat terendah". ${ }^{15}$ Ada beberapa pengawasan yang dapat menilai akuntabilitas Pemerintah yaitu:

1. Pengawasan internal, sebagai pengawasan yang dijalankan oleh pengawas terhadap bawahannya dalam unit kerjanya;

2. Pengawasan fungsional, pengawasan yang dilaksanakan oleh lembaga BPKP, BPK dan pengawasan legislatif adalah pengawasan yang dilakukanoleh DPR dan DPRD;

3. Pengawasan yudisial sebagai pengawasan yang dilaksanakan oleh MA dan MK, sebagai pengawasan terhadap Pemerintah dan DPR dalam bidang hukum dan terlaksananya kaidah konstitusi. ${ }^{16}$

Pengawasan dipandang dari "kelembagaan" yang dikontrol dan melaksanakan kontrol dapat dibedakan menjadi kontrol intern dan kontrol ekstern. (1) Kontrol intern adalah pengawasan yang dilakukan oleh suatu badan/organ yang secara struktural adalah masih termasuk organisasi dalam lingkungan pemerintah; (2) Kontrol ekstern adalah pengawasan yang dilakukan oleh badan/organ secara struktur organisasi berada di luar pemerintah dalam arti eksekutif. ${ }^{17}$

Pengawasan umuumnya ditujukan terhadap wetmatigheid, rechmatigheid, dan doelmatigheid. Pengawasan wetmatigheid ialah pengawasan yang menitikberatkan, apakah pelaksanaan telah dilakukan sesuai dengan peraturan perundang-undangan, pengawasan rechmatigheid adalah pengawasan yang meletakkan segi operasional pada hukum yang berlaku dengan menguji kepada dasar hukum yang berlaku, pengawasan doelmatigheid adalah pengujian terhadap efektifitas, efisiensi, dan keserasian pelaksanaan operasional. ${ }^{18}$

Pengawasan itu sendirijelas mempunyai tujuan, yakni:

1. Untuk mengetahui apakah pelaksanaan telah sesuai dengan rencana yang telah ditetapkan atau tidak;

2. Untuk mengetahui kesulitan-kesulitan apa yang dijumpai oleh Kepala Daerah dan para penyelenggara pemerintahan di daerah sehingga dengan demikian dapat diambil langkah-langkah perbaikan dikemudian hari;

3. Pengawasan bukanlah untuk mencari kesalahan, tetapi untuk memperbaiki kesalahan;

4. Pengawasan dilakukan untuk mendorong harmonisasi antara kebutuhan/keinginan rakyat dengan para penyelenggara pemerintahan di daerah;

5. Untuk mensinergikan antara program/kebijakan pemerintah dengan program/kebijakan pemerintah daerah. ${ }^{19}$

Pengertian Otonomi Daerah berdasarkan Undang-Undang Nomor 9 Tahun 2015 juncto UndangUndang Nomor 23 Tahun 2014, tentang Pemerintahan Daerah adalah hak, wewenang, dan kewajiban daerah otonom untuk mengatur serta mengurus sendiri urusan pemerintahan dan kepentingan masyarakat setempat sesuai dengan peraturan perundang-undangan. Berikut adalah beberapa pengertian otonomi daerah menurut para $\operatorname{ahli}^{20}$ :

a. Benyamien Hoesein, "otonomi daerah adalah pemerintahan oleh dan untuk rakyat di bagian wilayah nasional suatu negara secara informal berada di luar pemerintahan pusat".

b. Ateng Syarifuddin, "otonomi mempunyai makna kebebasan atau kemandirian tetapi bukan kemerdekaan melainkan kebebasan yang terbatas atau kemandirian itu terwujud atas pemberian kesempatan yang harus dapat dipertanggungjawabkan".

c. Syarif Saleh, "hak mengatur dan memerintah daerah sendiri di mana hak tersebut merupakan hak yang diperoleh dari pemerintah pusat".

d. F.Sugeng Istianto, "hak dan wewenang untuk mengatur dan mengurus rumah tangga daerah"

${ }^{15}$ Agussalim Andi Gadjong, Pemerintahan Daerah,(Bogor: Ghalia Indonesia, 2007), hlm. 261.

${ }^{16}$ La Ode Husen, Hubungan Fungsi Pengawasan DPR dengan BPK dalam Sistem Ketatanegaraan Indonesia,(Bandung: CV. Utomo, 2005), hlm. 32.

${ }^{17}$ Paulus Effendie Lotulung dalam Irfan Fachruddin.Op. Cit., hlm. 92.

${ }^{18}$ H.Bohari, Pengawasan Keuangan Negara, (Jakarta: Rajawali Pers, 1992), hlm. 24.

19 Adrian Sutedi,Implikasi Hukum atas Sumber Pembiayaan Daerah dalam Kerangka Otonomi Daerah, (Jakarta: Sinar Grafika, 2009), hlm. 206.

${ }^{20}$ Ani Sri Rahayu, Pengantar Pemerintahan Daerah Kajian Teori, Hukum dan Aplikasinya, (Jakarta: Sinar Grafika, 2018), hlm. 13. 
e. Mariun, "otonomi daerah adalah kebebasan yang dimiliki oleh pemerintahan daerah yang memungkinkan mereka untuk membuat inisiatif sendiri dalam rangka mengelola dan mengoptimalkan sumber daya yang dimiliki oleh daerahnya sendiri. Otonomi daerah merupakan kebebasan untuk dapat berbuat sesuai dengan kebutuhan masyarakat setempat".

f. Philip Malwood, "otonomi daerah adalah suatu pemerintah daerah yang memiliki kewenangan sendiri di mana keberadaannya terpisah dengan otoritas yang diserahkan oleh pemerintah guna mengalokasikan sumber material yang bersifat substansial mengenai fungsi yang berbeda".

Otonomi daerah harus didefinisikan sebagai otonomi bagi rakyat daerah dan bukan otonomi "daerah" dalam pengertian suatu wilayah/teritorial tertentu di tingkat lokal, kalau pun implementasi otonomi daerah dilakukan Pemerintah Daerah maka kewenangan itu harus dikelola secara adil, jujur, dan demokratis. ${ }^{21}$

Menurut Teguh Yuwono, mengutip pendapat Rondineli terdapat empat bentuk otonomi daerah, yaitu dekonsentrasi, delegasi, devolusi, privatisasi. ${ }^{22}$

\section{METODE PENELITIAN}

Tipe penelitian yang digunakan adalah penelitian yuridis normatif, penelitian ini menggunakan "pendekatan konseptual, pendekatan perundang-undangan, dan pendekatan sejarah"23.

Bahan-bahan hukum yang telah diperoleh, diinventarisasi dan diidentifikasi untuk digunakan sebagai bahan dalam menganalisis pokok permasalahan dalam penelitian ini. Identifikasi bahan hukum baik primer, sekunder, maupun tertier dilakukan secara kritis, logis, dan sistematis, dikumpulkan berdasarkan sistem kartu (card system), "yang memuat sumber yang tepat dari mana catatan itu diambil, informasi atau pendapat yang digunakan, pokok masalah serta kartu yang digunakan adalah kartu kutipan, kartu ulasan, kartu ikhtisar"24 hal ini dilakukan untuk mempermudah proses pengolahan data hukum tersebut, dengan demikian bahan hukum akan disusun dan digolongkan menurut bentuk, jenis dan tingkatnya. Adapun bahan hukum yang digunakan dalam penelitian ini adalah:

a. Bahan hukum primer terdiri dari peraturan perundang-undangan yang berhubungan dengan masalah yang dibahas seperti:UUD 1945, Undang-Undang, Peraturan Pemerintah, Peraturan Daerah,dan lain-lain.

b. Bahan hukum sekunder yaitu bahan hukum yang dapat memberikan penjelasan mengenai bahan hukum primer, seperti:rancangan undang-undang, hasil-hasil penelitian, hasil karya dari kalangan hukum baik berbentuk buku, jurnal hukum, makalah dan lain-lain.

c. Bahan hukum tertier yakni bahan hukum yang dapat memberikan petunjuk maupun penjelasan terhadap bahan hukum primer dan sekunder.Contohnya: kamus, ensiklopedia, indeks komulatif,dan lain-lain

Kemudian dianalisa dengan cara :

1) Menginterpretasikan semua peraturan perundang-undangan sesuai masalah yang dibahas.

2) Menilai bahan-bahan hukum yang berhubungan dengan masalah yang diteliti.

3) Mengevaluasi peraturan perundang-undangan yang berhubungan dengan masalah yang dibahas.

\section{HASIL DAN PEMBAHASAN}

Pengawasan adalah sebagian dari wewenang pemerintahan secara menyeluruh, karena pada tingkat terakhir Pemerintah Pusatlah yang harus bertanggung jawab mengenai seluruh penyelenggaraan membenarkan diadakannya pengawasan atas segala tindakan daerah, karena keutuhan Negara Kesatuan harus terpelihara. ${ }^{25}$ Dalam tulisan ini lebih menitikberatkan pengawasan pelaksanaan otonomi daerah.

Pengawasan administratif berbentuk pengawasan melekat yang diatur dalam Instruksi Presiden Nomor 15 Tahun 1983, Pasal 3 ayat (2) menyatakan pengawasan melekat dimaksud dilakukan:

a. Melalui penggarisan struktur organisasi yang jelas dengan pembagian tugas dan fungsi beserta uraiannya yang jelas pula;

${ }^{21}$ J.Kaloh, Mencari Bentuk Otonomi Daerah Suatu Solusi Dalam Menjawab Kebutuhan Lokal dan Tantangan Global, (Jakarta; Rineka Cipta, 2007), hlm. 10.

${ }^{22}$ Ani Sri Rahayu, Op.Cit., hlm. 24.

${ }^{23}$ Bahder Johan Nasution, Metode Penelitian Ilmu Hukum,(Bandung:Mandar Maju,2008), hlm. 92.

${ }^{24}$ Ibid., hlm. 106.

${ }^{25}$ Irawan Soedjito, Pengawasan Terhadap Peraturan Daerah dan Keputusan Kepala Daerah, (Jakarta: BinaAksara, 1983), hlm. 10 . 
b. Melalui perincian kebijaksanaan pelaksanaan yang dituangkan secara tertulis yang dapat menjadi pegangan dalam pelaksanaannya oleh bawahan yang menerima pelimpahan wewenang dari atasannya;

c. Melalui rencana kerja yang menggambarkan kegiatan yang harus dilaksanakan, bentuk hubungan antar berbagai kegiatan beserta sasaran yang harus dicapainya;

d. Melalui prosedur kerja yang merupakan petunjuk pelaksanaan yang harus jelas dari atasan kepada bawahan;

e. Melalui pencatatan hasil kerja serta pelaporannya yang merupakan alat bagi atasan untuk mendapatkan informasi yang diperlukan bagi pengambilan keputusan serta penyusunan pertanggungjawaban, baik mengenai pelaksanaan tugas maupun mengenai pengelolaan keuangan;

f. Melalui pembinaan personil yang terus menerus agar para pelaksana menjadi unsur yang mampu melaksanakan dengan baik tugas yang menjadi tanggungjawabnya dan tidak melakukan tindakan yang bertentang dengan maksud serta kepentingan tugasnya. ${ }^{26}$

Pengawasan ini sangat efektif untuk mengendalikan aparat pemerintah, efektifitas ini sehubungan dengan tiga sifat yang dimilikinya yakni tepat, cepat, murah, ${ }^{27}$ dan pengawasan fungsional diatur dalam Pasal 2 ayat(1) Instruksi Presiden Nomor 15 Tahun 1983, yang dimaksud pengawasan fungsional adalah pengawasan yang dilakukan oleh aparat yang diadakan khusus untuk membantu pimpinan dalm menjalankan fungsi pengawasan di lingkungan organisasi yang menjadi tanggungjawabnya, pada hakekatnya pengawasan ini bersifat relatif. ${ }^{28}$

Secara singkat penulis akan uraikan pengawasan berdasarkan Undang-Undang Nomor 32 Tahun 2004 tentang Pemerintahan Daerah dan Undang-Undang Nomor 23 Tahun 2014 tentang Pemerintahan Daerah.

Berdasarkan Undang-Undang Nomor 32 Tahun 2004 tentang Pemerintahan Daerah sebagaimana termuat dalam pasal 218 yang berbunyi sebagai berikut :

(1) Pengawasan atas penyelenggaraan pemerintahan daerah dilaksanakan oleh pemerintah yang meliputi:

a. Pengawasan atas pelaksanaan urusan pemerintahan di daerah

b. Pengawasan terhadap peraturan daerah dan peraturan kepala daerah

(2) Pengawasan sebagaimana dimaksud pada ayat (1) huruf (a) dilaksanakan oleh aparat pengawas intern Pemerintah sesuai dengan peraturan perundang-undangan.

Dalam penjelasan disebutkan pasal 218 ayat (1) huruf (a) "pengawasan yang dimaksud dalam ketentuan ini di maksudkan agar pelaksanaan berbagai urusan pemerintahan di daerah tetap dapat berjalan sesuai dengan standar dan kebijakan pemerintah berdasarkan peraturan perundang-undangan”. Huruf (b); "yang dimaksud dengan "Perda dan Peraturan Kepala Daerah" dalam ketentuan ini meliputi Perda Provinsi dan Peraturan Gubernur, Perda Kabupaten/ Kota dan Peraturan Bupati/ Wali Kota dan Peraturan Desa dan Peraturan Kepala Desa".Selanjutnya pengawasan terhadap peraturan daerah ini mekanismenya diatur dalam Pasal 145 yaitu sebagai berikut:

(1) Perda disampaikan kepada Pemerintah paling lama 7 hari setelah ditetapkan.

(2) Perda sebagaimana dimaksud pada ayat (1) yang bertentangan dengan kepentingan umum dan/ atau peraturan perundang-undangan yang lebih tinggi daat dibatalkan oleh pemerintah.

(3) Keputusan pembatalan Perda sebagaimana dimaksud pada ayat (2) ditetapkan dengan Peraturan Presiden paling lama 60 hari sejak diterimanya Perda sebagaimana dimaksud pada ayat 1.

(4) Paling lama 7 hari setelah keputusan pembatalan sebagaimana dimaksud pada ayat 3, kepala daerah harus memberhentikan pelaksanaan Perda dan selanjutnya DPRD bersama kepala daerah mencabut perda tersebut.

(5) Apabila provinsi / kabupaten / kota tidak dapat menerima keputusan pembatalan Perda sebagaimana dimaksud ada ayat (3) dengan alasan yanga dapat di benarkan oleh peraturan perundang-undangan, kepala daerah dapat mengajukan keberatan kepada Mahkamah Agung.

(6) Apabila keberatn sebagaimana dimaksud pada ayat (5) dikabulkan sebagian atau seluruhnya, putusan Mahkmah Agung tersebut menyatakan Peraturan Presiden menjadi batal dan tidak mempunyai kekuatan hukum.

\footnotetext{
26 Muchsan, Op. Cit., hlm. 40.

${ }^{27}$ Ibid, hlm. 41.

${ }^{28}$ Ibid, hlm. 43.
} 
(7) Apabila Pemerintah tidak mengluarkan Peraturan Presiden untuk membatalkan Perda sebagaimana dimaksud pada ayat (3), Perda dimaksud pernyatan berlaku.

Dalam Penjelasan Umum angka (9) Undang-Undang Nomor 32 Tahun 2004 tentang Pemerintah Daerah disebutkan sebagai berikut :

Pengawasan atas penyelenggaran pemerintah daerah adalah proses kegiatan yang ditujukan untuk menjamin agar pemerintah daerah berjalan sesuai dengan rencana dan ketentuan peraturan perundangundangan yang berlaku. Pengawasan yang dilakukan oleh Pemerintah terkait dengan penyelenggaraan urusan pemerintah dan utamanya terhadap peraturan daerah dan peraturan kepala daerah. Dalam hal pengawasan terhadap rancangan peraturan daerah dan peraturan daerah Pemerintah melakukan dengan 2 (dua) cara sebagai berikut :

1) Pengawasan terhadap rancangan peraturan daerah (RAPERDA), yaitu terhadap rancangan peraturan daerah yang mengatur pajak daerah, APBD, dan RUTR sebelum disahkan oleh kepala daerah terlebih dahulu dievalusai oleh Menteri Dalam Negeri untuk Raperda provinsi, dan oleh Gubernur terhadap Raperda provinsi, dan oleh Gubernur terhadap raperda kabupaten / kota. Mekanisme ini dilakukan agar peraturan tentang hal-hal tersebut dapat mencapi daya guna dan hasil guna yang optimal.

2) Pengawasan terhadap semua peraturan daerah yang termasuk dalam angka 1, yaitu setiap peraturan daerah wajib disampaikan kepada Menteri Dalam Negeri untuk provinsi dan Gubernur untuk kabupaten/kota untuk memperoleh klarifikasi. Terhadap peraturan daerah yang bertentangan dengan kepentingan umum dan peraturan yang lebih tinggi dapat dibatalkan sesuai mekanisme yang berlaku. Dalam rangka mengoptimalkan fungsi pembinaan dan pengawasan, Pemerintah dapt menerapkan sanksi kepada penyelenggaran pemerintah daerah tersebut. Sanksi dimaksud antara lain dapat berupa penataan kembali suatu daerah otonom, pembatalan pengangkatan pejabat, penangguhan dan pembatalan berlakunya suatu kebijakan daerah, keputusan kepala daerah, dan keputusan lain yang ditetapkan daerah serta dapat memberikan sanksi pidana yang diproses sesuai dengan peraturan perundang-undangan.

Kemudian dalam Undang-Undang Nomor 23 Tahun 2014 tentang Pemerintahan Daerah terkait pengawasan termuat pada bab Pembinaan dan Pengawasan, yang terdiri dari beberapa pasal, diantaranya :

\section{Pasal 373}

(1) Pemerintah Pusat melakukan pembinaan dan pengawasan terhadap penyelenggaraan Pemerintahan Daerah Provinsi.

(2) Gubernur sebagai wakil Pemerintah Pusat melkukan pembinaan dan pengawasan terhadap penyelenggaraan Pemerintahan Daerah kabupaten/kota.

(3) Pembinaan dan pengawasan sebagaimana dimaksud pada ayat (1) secara nasional dikoordinasikan oleh Menteri.

\section{Pasal 377}

(1) Menteri melakukan pengawasan umum terhadap penyelenggaraan Pemerintahan Daerah provinsi.

(2) Menteri teknis dan kepala lembaga pemerintah nonkementerian melaksanakan pengawasan teknis terhadap penyelenggaraan Pemerintahan Daerah provinsi sesuai dengan bidang tugas masing-masing dan berkoordinasi dengan Menteri.

(3) Pengawasan sebagaimana dimaksud pada ayat (1) dan ayat (2) dilaksanakan oleh Aparat Pengawas Internal Pemerintah sesuai dengan fungsi dan kewenangannya.

\section{Pasal 378}

(1) Gubernur sebagai wakil Pemerintah Pusat melakukan pengawasan umum dan pengawasan teknis terhadap penyelenggaraan Pemerintahan Daerah kabupaten/kota.

(2) Dalam melaksanakan pengawasan sebagaimana dimaksud pada ayat (1), gubernur sebagai wakil Pemerintah Pusat dibantu oleh perangkat gubernur sebagai wakil Pemerintah Pusat.

(3) Dalam hal gubernur sebagai wakil Pemerintah Pusat belum mampu melakukan pengawasan sebagaiman dimaksud pada ayat(1), gubernur sebagai wakil Pemerintah Pusat meminta bantuan untuk melakukan pengawasan kepada Pemerintah Pusat. 


\section{Pasal 379}

(1) Gubernur sebagai kepala daerah provinsi berkewajiban melaksanakan pembinaan dan pengawasan terhadap Perangkat Daerah provinsi.

(2) Dalam melaksanakan pembinaan dan pengawasan sebagaiman dimaksud pada ayat (1), gubernur dibantu oleh inspektorat provinsi.

\section{Pasal 380}

(1) Bupati/wali kota sebagai kepala daerah kabupaten/kota berkewajiabn melaksanakan pembinaan dan pengawasan terhadap Perangkat Daerah kabupaten/kota.

(2) Dalam melaksanakan pembinaan dan pengawasan sebagaiman dimaksud pada ayat (1), gubernur dibantu oleh inspektorat kabupaten/kota.

Pembinaan lebih ditekankan pada memfasilitasi upaya pemberdayaan Daerah Otonom, sedangkan pengawasan lebih ditekankan pada pengawasan represif untuk lebih memberikan kebebasan kepada Daerah Otonom dalam mengambil keputusan serta memberikan peran kepada DPRD dalam mewujudkan fungsinya sebagai badan pengawas terhadap pelaksanaan Otonomi Daerah. ${ }^{29}$

Untuk adanya tindakan pengawasan diperlukan beberapa unsur yaitu :

a. adanya kewenangan yang jelas yang dimiliki oleh aparat pengawas;

b. adanya suatu rencana yang mantap sebagai alat penguji terhadap pelaksanaan suatu tugas yang akan diawasi;

c. tindakan pengawasan dapat dilakukan terhadap suatu proses kegiatan yang sedang berjalan maupun terhadap hasil yang dicapai dari kegiatan tersebut;

d. tindakan pengawasan berakhir dengan disusunnya evaluasi akhir terhadap kegiatan yang dilaksanakan serta pencocokan hasil yang dicapai dengan rencana sebagai tolok ukurnya

e. untuk selanjutnya tindakan pengawasan akan diteruskan dengan tindak lanjut, baik secara administratif, maupun secara yuridis. ${ }^{30}$

Secara garis besar pengawasan itu dibedakan menjadi dua macam yaitu :

a. Pengawasan preventif, yaitu berupa hak memberikan pengesahan terlebih dahulu terhadap semua keputusan daerah sebelum peraturan daerah dijalankan.

b. Pengawasan represif, berupa hak menunda atau membatalkan sesuatu keputusan daerah (yang belum atau sudah berjalan) yang dianggap bertentangan dengan kepentingan umum, undang-undang, peraturanperaturan yang lebih tinggi tingkatannya. ${ }^{31}$

Ada beberapa cara untuk mengubah tata kerja pemerintah diantaranya, menyusun sistem keuangan internal yang dapat menjamin pengawasan yang efektif atas penggunaan sumber daya, membentuk mekanisme pengawasan internal, meningkatkan efektifitas pengawasan, melaksanakan pengawasan yang efektif atas harta kekayaan. ${ }^{32}$

Masih dalam hal pengawasan, yang "sifatnya fakultatif yaitu dalam rangka memberikan pertimbangan kepada Pemerintah Daerah terhadap rencana yang menyangkut kepentingan daerah" 33 dan dapat menjadi "sarana dalam menciptakan check and balances system pelaksanaan pemerintahan sampai pada tingkat terendah". ${ }^{34}$ Pengawasan terhadap penyelenggaraan pemerintahan daerah adalah proses kegiatan yang ditujukan untuk menjamin agar pemerintahan daerah berjalan sesuai dengan rencana dan ketentuan peraturan perundang-undangan yang berlaku. ${ }^{35}$

Ada banyak konsep yang telah muncul untuk pengukuran kinerja, salah satu diantaranya adalah pedoman yang disusun bersama antara Lembaga Administrasi Negara dengan Badan Pengawas Keuangan

${ }^{29}$ Deddy.S.B, Dadang.S, Otonomi Penyelenggaraan Pemerintahan Daerah, (Jakarta: Gramedia Pustaka Utama, 2002), hlm. 9 .

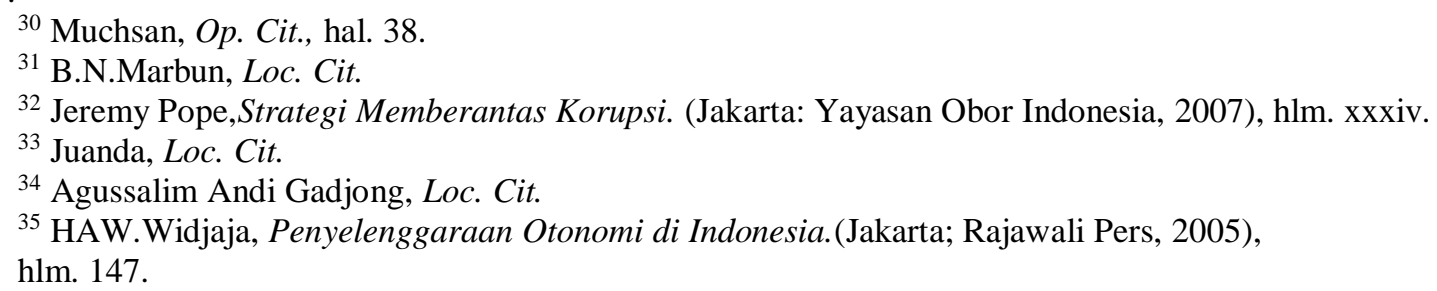


dan Pembangunan, mereka menggunakan singkatan AKIP (Akuntabilitas Kinerja Instansi Pemerintah) untuk pedoman tersebut, yang menarik dalam Laporan itu adalah uraian tentang Rancangan Indikator Kinerja. ${ }^{36}$ Pelaksanaan AKIP harus berdasarkan pada prinsip-prinsip sebagai berikut:

1. Adanya komitmen dari pimpinan dan seluruh staf instansi yang bersangkutan.

2. Berdasarkan suatu sistem yang dapat menjamin penggunaan sumber-sumber daya secara konsisten dengan peraturan perundang-undangan yang berlaku.

3. Menunjukkan tingkat pencapaian sasaran dan tujuan yang telah ditetapkan.

4. Berorientasi pada pencapaian visi dan misi, serta hasil dan manfaat yang diperoleh.

5. Jujur, objektif, transparan, dan akurat.

6. Menyajikan keberhasilan/kegagalan dalam pencapaian sasaran dan tujuan yang telah ditetapkan. ${ }^{37}$

Dengan demikian otonomi, adalah kebutuhan dibukanya kesempatan pada daerah untuk menata diri sesuai dengan potensi dan kapasitas yang dimilikinya; lebih dari itu, agar daerah berkembang sejalan dengan sejarah atau asal-usul daerah tersebut. ${ }^{38}$

Dari uaraian tersebut diatas, dapat disimpulkan bahwa untuk adanya tindakan pengawasan diperlukan unsur-unsur sebagai berikut :

a. Adanya kewenangan yang jelas dimiliki oleh aparat pengawas;

b. Adanya suatu rencana yang mantap sebagai alat penguji terhadap pelaksanaan suatu tugas yang akan diawasi;

c. Tindakan pengawasan dapat dilakukan terhadap suatu proses kegiatan yang sedang berjalan maupun terhadap hasil yang dicapai dari kegiatan tersebut;

d. Tindakan pengawasan berakhir dengan disusunnya evaluasi akhirterhadap kegiatan yang dilaksanakan serta pencocokan hasil yang dicapai dengan rencana sebagai tolok ukurnya;

e. Untuk selanjutnya tindakan pengawasan akan diteruskan dengan tindak lanjut baik secara administratif maupun secara yuridis. ${ }^{39}$

Oleh karena itu, "hukum merupakan instrumen utama dalam penyelenggaraan pemerintahan Indonesia", ${ }^{40}$ H.W.R.Wade mengidentifikasi lima pilar negara hukum sebagai berikut:

1. semua tindakan pemerintah harus menurut hukum,

2. pemerintah harus berprilaku di dalam suatu bingkai yang diakui peraturan perundang-undangan dan prinsip-prinsip yang membatasi kekuasaan diskresi,

3. sengketa mengenai keabsahan tindakan pemerintah akan diputuskan oleh pengadilan yang murni independen dari eksekutif,

4. harus seimbang antara pemerintah dan warga negara,

5. tidak seorangpun dapat dihukum kecuali atas kejahatan yang ditegaskan menurut undang-undang. ${ }^{41}$

Dari uraian tulisan diatas dapat diketahui bahwa pengawasan itu tindakan yang dilakukan secara terusmenerus, berawal dari perencanaan, pelaksanaan, dalam hal pengawasan pelaksanaan otonomi daerah dilakukan berdasarkan peraturan perundangn-undangan terkait serta asas-asas umum pemerintahan yang baik.

\section{SIMPULAN}

Pengawasanpelaksanaan otonomi daerah yang dilakukan Pemerintah Pusat melalui wakilnya jangan sampai mengganggu kemandirian otonomi daerah, tentunya diperlukan aturan yang cermat dan bijaksana.

${ }^{36}$ H. Syahruddin, Werry Darta Taifur, "Peranan DPRD Untuk Mencapai Tujuan Desentralisasi”, (Padang: Pusat Studi Kependudukan Universitas Andalas,2002), hlm.60.

${ }^{37}$ BPKP, “Akuntabilitas Instansi Pemerintah”, (Jakarta: Modul Edisi Kelima, 2007), hlm. 7.

${ }^{38}$ J.Kaloh, Op.Cit., hlm. 31.

${ }^{39}$ Muchsan, Op.Cit., hlm. 38.

${ }^{40}$ H.Abdul Latief, Op. Cit., hlm. 21.

${ }^{41}$ La Ode Husen, Op. Cit., hlm. 45. 


\section{DAFTAR PUSTAKA}

\section{Buku}

Abdullah, Rozali, Pelaksanaan Otonomi Luas Dengan Pemilihan Kepala Daerah Secara Langsung, Jakarta: Rajawali Pers, 2005.

Asshidiqie, Jimly, Pengantar Ilmu Jukum Tata Negara,Jakarata:Rajawali Pers,2009.

Bohari, H, Pengawasan Keuangan Negara, Jakarta: Rajawali Pers,1992.

Fachruddin, Irfan, Pengawasan Peradilan Administrasi Terhadap Tindakan Pemerintah,Bandung: PT.Alumni, 2004.

Gadjong, Agussalim Andi, Pemerintahan Daerah,Bogor: Ghalia Indonesia, 2007.

Husen, La Ode, Hubungan Fungsi Pengawasan DPR dengan BPK dalam Sistem Ketatanegaraan Indonesia, Bandung: CV.Utomo, 2005.

Juanda, Hukum Pemerintahan Daerah Pasang Surut Hubungan Kewenangan Antara DPRD dan Kepala Daerah,Bandung: PT.Alumni, 2008.

Kaligis, O.C, Pengawasan Terhadap Jaksa Selaku Penyidik Tindak Pidana Khusus dalam Pemberantasan Korupsi, Bandung: PT.ALUMNI,2006.

Kaloh, J, Mencari Bentuk Otonomi Daerah Suatu Solusi Dalam Menjawab Kebutuhan Lokal dan Tantangan Global, Jakarta; Rineka Cipta, 2007.

Latief, H.Abdul, Hukum dan Peraturan Kebijaksanaan pada Pemerintahan Daerah,Yogyakarta: UII Press, 2005.

Manan, Bagir, Menyongsong Fajar Otonomi Daerah, Yogyakarta: Pusat Studi Hukum FH UII, 2001.

Marbun, B.N,Otonomi Daerah 1945-2005 Proses dan Realita,Jakarta: Pustaka Sinar Harapan, 2005.

MD Ulum, Ihyaul, Audit Sektor Publik, Jakarta: Bumi Aksara, 2009.

Muchsan,Sistem Pengawasan Terhadap Perbuatan Aparatur Pemerintah dan Peradilan Tata Usaha Negara di Indonesia, Yogyakarta: Liberty, 2007.

Nasution, Bahder Johan, Metode Penelitian Ilmu Hukum, Bandung:Mandar Maju,2008.

Pope, Jeremy, Strategi Memberantas Korupsi, Jakarta: Yayasan Obor Indonesia, 2007.

Rahayu, Ani Sri, Pengantar Pemerintahan Daerah Kajian Teori, Hukum dan Aplikasinya, Jakarta: Sinar Grafika, 2018.

S.B, Deddy, S, Dadang, Otonomi Penyelenggaraan Pemerintahan Daerah, Jakarta: Gramedia Pustaka Utama, 2002.

Sutedi, Adrian,Implikasi Hukum atas Sumber Pembiayaan Daerah dalam Kerangka Otonomi Daerah, Jakarta: Sinar Grafika, 2009.

Soedjito, Irawan, Pengawasan Terhadap Peraturan Daerah dan Keputusan Kepala Daerah, Jakarta: BinaAksara, 1983.

Widjaja, HAW, Penyelenggaraan Otonomi di Indonesia. Jakarta; Rajawali Pers, 2005.

Jurnal

BPKP, Akuntabilitas Instansi Pemerintah, Jakarta: Modul Edisi Kelima, 2007.

Syahruddin, H, Taifur, Werry Darta, Peranan DPRD Untuk Mencapai Tujuan Desentralisasi, Padang: Pusat Studi Kependudukan Universitas Andalas,2002.

Hasan Mustafa, SDM dan Otonomi Daerah, Palu: 2002.

\section{Internet}

Sebastian Schrnieg, "DPRD dan Pengawasan", http://sebastianschrnieg. wordpress.com, tanggal diakses 16 Agustus 2018.

\section{Peraturan Perundang-undangan}

Republik Indonesia.Undang-Undang Tentang Pemerintahan Daerah. Undang-Undang Nomor 32 Tahun 2004.

Republik Indonesia.Undang-Undang Tentang Pemerintahan Daerah. Undang-Undang Nomor 23 Tahun 2014.

Republik Indonesia.Undang-Undang Tentang Pemerintahan Daerah. Undang-Undang Nomor 9 Tahun 2015. 